\title{
Using M-Learning Technology in Teaching Foreign Languages: A Panacea during COVID-19 Pandemic Era
}

\author{
https://doi.org/10.3991/ijim.v15i15.22895 \\ Elena Dolzhich ${ }^{1(凶)}$, Svetlana Dmitrichenkova ${ }^{1}$, Mona Kamal Ibrahim²,3 \\ ${ }^{1}$ Peoples' Friendship University of Russia (RUDN University), \\ Moscow, Russian Federation \\ ${ }^{2} \mathrm{Al}$-Ain University, Al Ain, United Arab Emirates \\ ${ }^{3}$ Helwan University, Helwan, Egypt \\ dolzhichele@rambler.ru, korte@mail.ru
}

\begin{abstract}
The purpose of the study is to analyze the prospects for the widespread use of mobile applications in teaching English as a foreign language (EFL) in Russia to Russian and Arab learners. The survey was conducted at the Department of Foreign Languages of the Engineering Academy of the Peoples' Friendship University of Russia (EA PFUR). The total research sample included 200 participants and consisted of 50 potential employers, 50 Russian and Arab PFUR linguistics students, 50 faculty members, namely, teachers of PFUR, the Institute of Foreign Languages of the Moscow State Pedagogical University, and the Moscow Institute of Physics and Technology, as well as 50 PFUR administrative staff members. The purpose of the survey was to collect information about mobile applications (Smartphone Apps) and the introduction of mobile learning technology (m-learning) in the process of teaching EFL to students. According to the survey results, instructors actively use mobile technologies in their professional activities, and all participants in the learning process are receptive to their introduction to education. At the same time, respondents believe that technical challenges are the major obstacle to adopting mobile applications; these problems must be overcome to enable more productive use of mobile applications.
\end{abstract}

Keywords - foreign languages, English as a foreign language (EFL), graduate education, mobile-assisted language learning (MALL), MALL technology, mobile learning (m-learning), smartphone application

\section{Introduction}

E-learning methodologies have become increasingly popular in higher education, along with the development of information technologies. However, in recent years, as a result of the active development of mobile technologies and the introduction of mobile devices (smartphones, tablets, and other gadgets) in almost all spheres of socio-economic life, a new approach has appeared - mobile learning (m-learning), 
which is developing in the higher education system along with online learning. This form of education involves the use of resources and capabilities of mobile devices and specially designed and adapted mobile applications. Thus, the educational process may no longer be limited to a computer classroom, classroom, or student's home workplace connected to the Internet. This contributes to the mobility and flexibility of the educational process, which is especially important when learning foreign languages as language practice often takes place far from fixed places of study (for example, international exhibitions, fairs, conferences, seminars). The use of mobile applications by students, such as chats (WhatsApp), online translators (Google Translate), electronic dictionaries (ABBYY Lingvo), can significantly increase the effectiveness of learning foreign languages, nevertheless learning EFL.

The m-learning technology is gaining particular importance in the context of the COVID-19 pandemic, which, according to researchers, has affected 213 countries that have been forced to switch to distance learning that involves both stationary and mobile devices [1]. The purpose and scope of this research focus on obstacles and problems arising from the implementation of online and mobile learning, being similar in different countries.

\subsection{M-learning and mobile-assisted language learning technology}

Gangaiamaran and Pasupathi define m-learning as using the mobility of personal portable and wireless devices, such as a smartphone, pocket computer, iPod, laptop, in the learning process. In this case, mobility refers to the mobility of technology, the learner, and the learning process [2]. Mobile learning includes the following four components: education, communication; organization; technical content [3]. Mobile-assisted language learning (MALL) is a type of m-learning and Computer-Assisted Language Learning (CALL). Many early MALL projects used SMS to teach new vocabulary by occasionally sending students messages with word lists, sample sentences, or study reminders [4]. In the study devoted to the effectiveness of MALL, Haerazi et al. showed that the MALL model is a more effective way to develop writing skills compared to other learning approaches [5].

Mobile learning is an integral part of distance learning. At the same time, MALL involves the independent study of a foreign language. For the Russian educational context, the leading problems are an increase in training volume and a decrease in teaching hours of a foreign language in non-core areas of a university [6,7]. For the Western educational context, more significant issues are measuring the quality and effectiveness of mobile applications and learning in a digital environment from primary school age $[8,9]$. According to other Russian researchers (A. Beloglazov, L. Beloglazova, etc.), leading universities are beginning to perceive mobile devices as an opportunity to expand the learning experience [10] significantly. For both developing and developed countries, the perception and ability to use mobile learning among teachers are critical factors $[11,12]$.

\subsection{Smartphone apps for teaching and learning foreign languages}

Several mobile applications are used in different countries to learn foreign languages effectively. The Apple Store (https:/www.apple.com/shop) and the Google Play 
(https://play.google.com/store/apps) platforms provide a large number of mobile apps for students and teachers to download, but their value and effectiveness in learning activities require further careful research [13].

Nevertheless, recently, the most popular and requested apps for learning a foreign language have been distinguished, for example, mobile applications for learning a language "from scratch", namely Duolingo, LinguaLeo, etc. In addition, according to Lotherington, the list includes Babbel, Busuu, and Memrise [14].

Khalitova and Gimaletdinova believe that Instagram can serve as an effective tool in learning English as a foreign language (EFL) by advanced students - it improves listening skills, particularly the ability to understand opinions and authentic information [15]. Studies of the effectiveness of mobile applications for learning Russian as a foreign language is of interest. Thus, Al-Kaisi et al. suggest using the Alisa virtual assistant, developed by the Russian company Yandex, for independent mastering of the basic level of the Russian language by international students. The researchers note the didactic potential of this mobile application to enhance independent work [16]. The mobile plugin developed at PFUR - RUDN CourseAssist - promotes English grammar and is also helpful for students wishing to obtain a qualification defined by the Common European Framework of Reference for Languages (CEFR) [17]. The use of online dictionaries as mobile applications for learning foreign languages offline confirms the effectiveness of the MALL technology in learning and teaching. Modern electronic dictionaries, such as ABBYY Lingvo Dictionaries and U-Dictionary, offer users exercises for context vocabulary acquisition to develop reading, speaking, and listening skills. In addition, they play an important role in preparation for international exams such as PET, FCE, CAE (advanced), CPE (proficiency), and others [18]. According to Alvarado et al. the Audioboom app - a voice platform, a podcast, and a social media network that allows users to record, listen to, and share an unlimited number of podcasts or audio files, is an effective m-learning tool. Thus, the platform enables listeners to create content and send it to other websites and mobile applications, such as Facebook, Twitter, etc., making it more dynamic, interconnected, and engaging. Like many other web-based tools, AudioBoom was initially designed as a website that evolved into an app for iOS and Android devices after its successful implementation [19].

\subsection{Features of using mobile applications in different countries}

The use of the MALL technology to study foreign languages has its characteristics in Russia and other countries. For example, Lyovina notes that there are noticeably fewer mobile applications for learning Russian as a foreign language than applications for learning English [20]. Odinokaya and Lebedev also cite data that almost half (46\%) of users quit mobile educational platforms as they lose interest in them. Only $14 \%$ of the people surveyed effectively learn a foreign language through mobile educational platforms [21]. A group of PFUR scientists, considering the methodological and technical aspects of the implementation of mobile foreign language learning, have noted significant advantages of individual mobile applications in teaching EFL, their capability to activate all types of verbal activity, and more opportunities for individual work. At the same time, scientists have noted that teachers are faced with creating highly effective teaching materials [22]. 
Most Arab countries have launched their e-learning and m-learning initiatives to integrate the latest educational technologies. The prevalence of mobile phones among Arabs and the availability of good mobile infrastructure are essential factors that can facilitate the transition to m-learning. In addition, many studies [23-31] indicate a positive attitude to and perception of m-learning in various Arab educational institutions.

In the UAE, mobile learning technology in teaching foreign languages also has its characteristics and differences from the Russian experience. Some researchers believe that m-learning is inextricably linked to professional development and focuses on the availability of educational videos, gamification of content, and easy navigation necessary for effective learning [32]. According to researchers, in the Arab states of the Persian Gulf, UAE students have a more positive attitude towards the use of mobile applications to learn foreign languages in general and EFL in specific, compared to students in Oman; $81.5 \%$ of Arab students use mobile devices in their studies while only $18.5 \%$ do not [33]. In comparison with this experience, the experience of Greece is exciting, where the use of mobile applications and teaching methods is already widespread [34]. Such examples can serve as a guideline for implementing mobile learning already at the preschool stage to prepare a person for learning in a digital environment at a more mature age $[35,36]$.

Studies on the introduction of Mobile-Assisted Language Learning in other countries are also of interest. For example, the cost of tablets may discourage some students from purchasing those [37]. A study of the effectiveness of Android applications in teaching English vocabulary conducted in Indonesia is also noteworthy [38]. Chinese researchers Liu and He have confirmed a positive relationship between the selected applications and improved student knowledge of the English language [39].

There are various approaches to mobile applications both in the educational process and in teaching English as a foreign language, in particular. The most pressing problem, which this study is devoted to, is the degree of distribution of mobile applications, the variety of their use, and the presence of many common problems for many countries that stand in the way of the implementation of mobile and online learning.

The study aims to analyze the prospects for the widespread use of mobile applications in teaching EFL in Russia. Based on this, the research task is to study how widespread mobile applications for learning a foreign language are and what the main obstacles stand in the way of their more comprehensive application for Russian and Arab students.

Based on this, the following research objectives have been set:

- studying the principles, features, and potential of mobile learning in the context of teaching English as a foreign language in Russia to Russian and Arab learners;

- considering mobile applications for learning foreign languages that are most popular in Russia, as well as identifying their advantages and disadvantages;

- analyzing the attitude of the educational process participants to the implementation of mobile applications in professional and educational activities;

- substantiating the feasibility and necessity of mobile applications in the educational process and in teaching English as a foreign language.

The research consists of an Introduction outlining the objectives and the background of the research; the next section, Methodology, describes the methods of conducting 
empirical research and gives an example of the questionnaire used. The results analyze the findings and descriptive statistics; the Discussion section describes how the findings relate to similar studies, and the Conclusions section suggests summaries of the study.

\section{Methodology}

In the study, an online survey based on a questionnaire consisting of four open and closed questions was conducted. An empirical method was applied to collect research data to analyze further the degree of the use of mobile applications in the educational process and the prospects of the MALL technology in teaching English as a foreign language.

\subsection{Development of the questionnaire}

The survey of respondents was based on an online questionnaire that contained both open and closed questions. There were four questions in the interactive online questionnaire constructed in Google Forms (https://forms.google.com) and distributed among students, university representatives, and employers to collect their opinions on mobile learning and mobile applications used in the educational process. In addition, the questions were adapted for students, teachers, employers, and the administrative staff.

The online questionnaire contained the following four questions: question (1) was a closed question about the use of mobile devices in the professional or educational activities of the respondent, which had two answer options: $1=$ Yes, I do; 2 = No, I do not; additionally, respondent was asked to name professional mobile applications that are most often used by him/her; in open-ended questions (2), (3) and (4), the respondents had to select answer options and mark them with $(\odot)$.

The question form was chosen to obtain immediate score values for descriptive statistics without checking the validity and reliability of the questions. The content of the questions and the options for choosing were formulated based on numerous studies on obstacles in the implementation of online learning [2,19,25].

\subsection{Participants}

The empirical research was conducted based on two universities: the Department of Foreign Languages of the Engineering Academy of PFUR (IA RUDN University); Department of Foreign Languages of EA PFUR. The research sample consisted of potential employers (50 people), Russian and international students of PFUR (50 people) studying linguistics (training program code 035700 ), faculty members, namely, teachers of PFUR, the Institute of Foreign Languages of the Moscow State Pedagogical University, and the Moscow Institute of Physics and Technology (50 people), as well as the administrative staff of PFUR (50 people). The total number of participants was 200 people. Considering the size of the general sample for each of the groups of 50 people (for example, the number of students of the faculty), the value of the admissible sampling error did not exceed $p=2.74$. Thus, the sample used can be considered to be representative. 


\subsection{Data collection}

A mail-out of the questionnaire link was sent to the research participants from different organizations and universities via Gmail to avoid bias in the collection of the survey data. The purpose of the survey was to collect information about mobile applications (Smartphone Apps) and the introduction of mobile learning technology (m-learning) in the process of teaching English as a foreign language to students. The data analysis was conducted in Microsoft Office Excel in order to obtain research results. Descriptive statistics based on the qualitative research methodology were used to analyze the obtained statistical data.

\subsection{Research limitations}

The limitation of the study involves the fact that the collection of data took place at three Russian universities. In addition, there were only 50 people in each group of respondents. Moreover, the study relied exclusively on the online survey method to collect the data, which does not involve multiple questions to avoid misinterpretations and incorrect answers. In the future, the empirical research tool is expected to be improved to conduct similar studies at other Russian universities. To increase the relevance of the sample, the number of respondents will be increased. In addition to surveys, interviews will also be used to collect the research data.

\section{$3 \quad$ Results}

\subsection{An empirical study of implementing m-learning in teaching English as a foreign language}

The results of the empirical study are described below.

Question 1 was addressed to potential employers; they were asked to note whether they use mobile devices in professional activities and name professional mobile applications that are most often used (Table 1).

Table 1. Use of mobile applications in professional activities related to EFL (\%)

\begin{tabular}{|l|l|}
\hline \multicolumn{2}{|c|}{ The Use of Mobile Devices } \\
\hline \multicolumn{2}{|c|}{ Mobile Applications Most Often Used } \\
\hline Duolingo & 78 \\
\hline Google Translate & 31 \\
\hline ABBYY Lingvo Dictionaries & 29 \\
\hline WhatsApp & 17 \\
\hline Others & 14 \\
\hline
\end{tabular}

The results obtained indicate that modern linguists actively (78\%) use mobile technologies in their professional activities. At the same time, Duolingo is the most popular application used for self-learning and increasing linguistic competence (31\%); 
the second place is taken by Google Translate (29\%), which is followed by ABBYY Lingvo Dictionary that allows offline translation (17\%) and WhatsApp (14\%) used to exchange professional experience and study independently. Only $9 \%$ of respondents use alternative mobile applications, indicating some professional standards in their activities.

Question 2. At the next stage, the survey participants were asked to express their attitude to the introduction of mobile technologies in teaching EFL to students (Table 2).

Table 2. Feasibility and necessity of implementing mobile learning technology (m-learning) in teaching foreign languages $(\%)$

\begin{tabular}{|l|c|c|}
\hline & Positive Attitude & Negative Attitude \\
\hline Potential employers & 92 & 8 \\
\hline Students (Russian and Arab) & 98 & 2 \\
\hline Teachers & 72 & 28 \\
\hline The administrative staff of a university & 79 & 21 \\
\hline
\end{tabular}

The results obtained show that all participants in the educational process support mobile technologies in education. At the same time, the indicators of potential employers $(92 \%)$ and students $(98 \%)$ are slightly higher than those of the representatives of universities ( $72 \%$ and $79 \%$, respectively), which may indicate some rigidity of higher education system in Russia.

Question 3. The next stage involved students and the representatives of Russian universities - the question related to the accessibility of MALL technology for students and teachers (Table 3).

Table 3. The accessibility of the Mobile-Assisted Language Learning (MALL) technology (\%)

\begin{tabular}{|l|c|}
\hline & $\begin{array}{c}\text { Accessibility of the Mobile-Assisted Language } \\
\text { Learning (MALL) Technology }\end{array}$ \\
\hline Students (Russian and Arab) & 70 \\
\hline Teachers & 58 \\
\hline Administrative university staff & 74 \\
\hline
\end{tabular}

The administrative university staff is the most optimistic about the issue, while teachers have shown the lowest indicators. This is primarily because teachers are more realistic about assessing the possibilities of regular and organized use of mobile devices by students for educational purposes.

Question 4. At the final stage, the survey participants were asked to note the significant obstacles to introducing m-learning into the educational process (Table 4).

Table 4. Major obstacles to the introduction of m-learning into the educational process (\%)

\begin{tabular}{|l|c|c|c|}
\hline & $\begin{array}{c}\text { Administrative } \\
\text { Factor }\end{array}$ & $\begin{array}{c}\text { Technical } \\
\text { Problems }\end{array}$ & $\begin{array}{c}\text { Psychological } \\
\text { Unpreparedness }\end{array}$ \\
\hline Students (Russian and Arab) & 14 & 58 & 4 \\
\hline Teachers & 12 & 72 & 30 \\
\hline Administrative university staff & 6 & 32 & 22 \\
\hline
\end{tabular}


The survey results indicate that technical problems come to the fore (network availability, security of all mobile devices of the participants in the educational process, power outages, etc.). The low values of the "administrative factor" and "psychological unpreparedness" indicators demonstrate that Russian universities are ready to switch to mobile learning; the only thing that should be done is to improve university facilities and resources.

\subsection{Principles of teaching foreign languages with mobile apps}

In higher education, the development of mobile technologies and the introduction of relevant applications to teach and study foreign languages have opened up many new opportunities both for students who need to cope with a complex and rapidly changing array of information. Teachers who use mobile devices to facilitate instruction intensify the educational process, increase students' motivation, and, as a result, accelerate the achievement of learning outcomes.

Currently, several universities are creating mobile-optimized websites and standalone applications that can be downloaded on mobile devices. They also use mobile technologies to send students information and educational resources, complete and check assignments, control and monitor knowledge and provide fast and effective feedback (for example, online testing at PFUR http://inyaz.rudn.ru/testirovanie-po-yazikam, MOODLE plugin "RUDNCourseAssist" for accelerated learning of grammar).

It is important to note that the virtual workplace of a teacher and a student-organized based on MALL technology requires three significant competencies: technical, communication, and organizational (production and management); thus, a modern foreign language teacher must be able to use the whole range of functions of a mobile device, as well as to competently establish contact with other people and organize the educational process.

The authors believe that in connection with the digitalization of education and the emergence of a specific mobile learning environment, the regulatory documents of universities should be amended to clarify and specify the competencies associated with the use of mobile applications for learning foreign languages. It is advisable to involve all participants in the educational process, and first of all the representatives of foreign companies, that is, potential employers, whose practical experience is of particular importance. In addition, professional development and retraining are quite expensive. Therefore, the representatives of enterprises and companies will be happy to support the initiative to adjust training programs that will allow students to acquire essential skills while studying at university.

An essential objective of higher education is to determine the principles of selecting educational activities based on mobile applications in the process of teaching a foreign language.

As mobile devices become increasingly versatile, the range of educational tasks and activities is expanding. Foreign language teachers should master specialized mobile applications, such as:

- the ABBYY Lingvo Dictionaries for Android and iOS (translation of words, images, and videos); 
- Google Translate, which allows users to instantly translate words, phrases, and web pages into more than 100 languages with the help of artificial neural networks (neural machine translation);

- Duolingo, which enables one to learn any language from scratch;

- WhatsApp, which allows users to collaborate with other teachers and students as the application can be used to read and write texts and practice listening and speaking skills in English.

Special mobile applications facilitate online teaching of foreign languages, increase productivity, and optimize quality control of knowledge - this makes them an indispensable tool for a modern teacher. Teaching students to use them at the stage of university education contributes to the successful completion of the curriculum and increases the competitiveness of graduates in the labor market.

When selecting educational activities involving mobile applications, it is crucial to guide certain principles described in Figure 1.

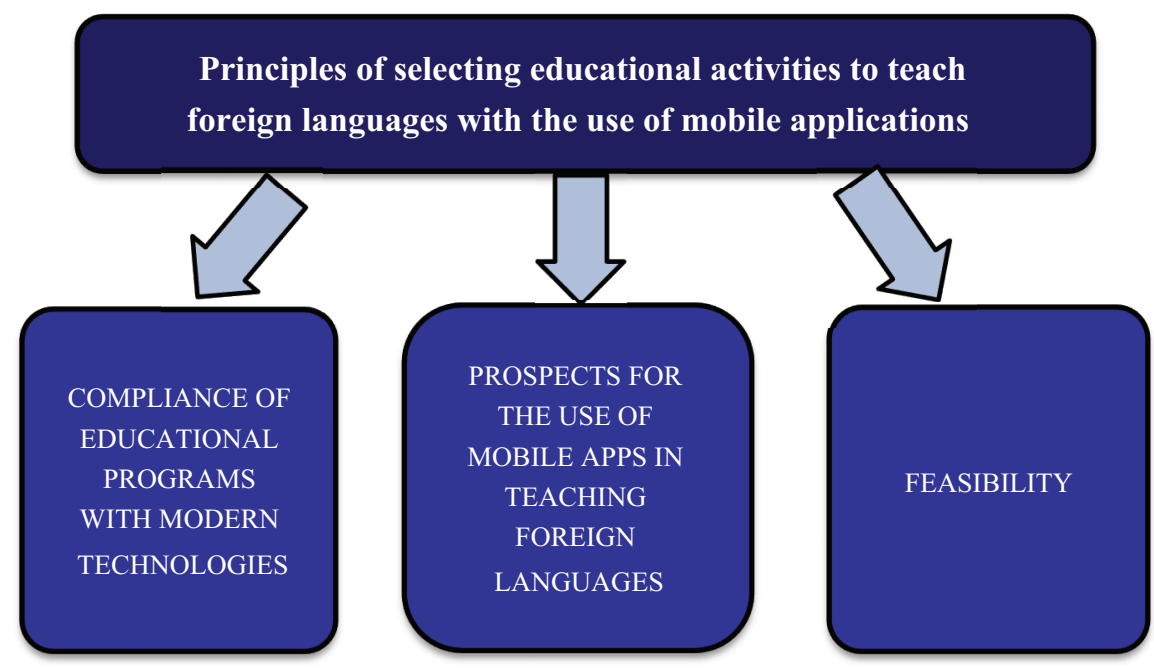

Fig. 1. Principles of selecting educational activities to teach foreign languages with the use of mobile applications

Thus, mobile applications form the basis for the development of students' linguistic competencies. Due to this, they consistently simulate professional activities, which ensure the gradual transformation of academic activity into the quasi-professional, and later into the professional activity of a translator, secretary, teacher, or international observer.

\section{Discussion}

The available mobile language learning apps have both advantages and disadvantages. CEFR tried to determine whether these applications contain language activities contributing to reading, writing, listening, speaking, and language learning [40]. 
Firstly, mobile language learning applications are effective in personal and student-centered learning experiences and ubiquitous language resources. It develops a sense of individuality in students and a healthy lifelong learning habit. Students, especially in the presence of skills imparted in preschool age, can easily and independently access language learning materials and tools then and there; thus, their motivation to learn the language increases $[11,12,41]$.

The most pressing issues identified by the present study are less accessibility and less acceptance of mobile learning and devices and apps among educators. These problems have been adequately considered, and their solutions have been proposed in several studies $[11,36]$, but for Russia and the UAE they remain relevant. Researchers focus on individuality and believe that personal mobile devices involve students in more flexible, accessible, and personalized learning without any restrictions related to the place and time of the study. This explains the more positive attitudes revealed and the more frequent use of mobile applications by students in the current study. The advantages of mobile applications in education include increased social interaction, entertainment, 24/7 availability, efficient leisure time, alternative learning methods, and an informal learning environment [2]. According to Kacetl and Klímová, the advantage of MALL also includes an improvement in students' cognitive abilities, their motivation to learn in both formal and informal settings, independence and confidence to study, as well as the fact that this technology promotes individual learning and helps students with poor performance achieve their academic goals [42]. Godwin-Jones notes that the most important reason for using mobile applications in teaching foreign languages is using mobile devices outside educational institutions. The MALL technology provides great potential for language learning as students can participate in several non-formal learning environments: casual (a game), instrumental (the use of a service or an app to learn a language), or secondary (code-switching in a YouTube video). An activity related to the study of the language is chosen by the student and not by the teacher [4]. Indian researchers, Jamaldeen et al. point out that $\mathrm{m}$-learning can be effective when implemented in a blended learning environment and other teaching and learning methods [43].

Along with the advantages of MALL, many researchers note the disadvantages of this technology. Thus, Godwin-Jones argues that in most MALL projects, the emphasis is placed on exercises rather than the communication activities of students [4]. According to Klimova, the disadvantages of the MALL technology include the potential loss of student interest during online classes due to the multitasking nature of mobile devices; lack of applications suitable for studying specialized English courses (EnglishforSpecificPurposes, ESP); Internet access and connection problems, small display size and lack of personal contact [44]. Kramsch, on the one hand, highlights such advantages of mobile learning as increased enthusiasm of students, a more significant number of language exercises, and, on the other hand, emphasizes the technology disadvantages identified by foreign language teachers - more remarkable superficiality of content and greater egocentricity compared to traditional learning [45].

The researchers [46] propose using the advantages of mobile applications in listening activities by developing and using virtual reality technology (VR applications). Unlike traditional listening exercises based on audio files, Virtual Reality apps allow students to immerse themselves in the virtual world, a formal and informal scenario [46]. 
Oyelere et al. analyze changes in the educational system of the Russian Federation and come up with an approach based on the active "mobilization" of foreign language teaching. Thus, they propose reducing offline classroom hours and the introduction of links to mobile and online resources on each topic in the student's syllabus [47].

Valeeva et al. believe that students' development of active context vocabulary is an important result of the MALL technology. According to the researchers' data, more than $90 \%$ of students positively assessed mobile applications for educational purposes [48], which coincides with the results obtained in the present research (Table 2).

Some practitioners are developing their mobile applications to study using the MALL technology in teaching foreign languages. For example, the Basic4Android smartphone application (named WordLearning-CET6), which promotes learning English vocabulary, was developed by the Chinese scientessential [49]. Other Chinese scholars, Xu and Peng, investigated the impact of the MALL technology on learning Chinese as a second language (CSL) and concluded that the social communication app for smartphones, WeChat stimulates verbal feedback and enhances students' communication skills [50,51].

\section{$5 \quad$ Conclusion and future work}

The research aimed to obtain information on the prospects for the use of mobile applications in teaching EFL. Based on the study of the features of mobile learning, the advantages and disadvantages of MALL technology in teaching foreign languages have also been highlighted.

The most popular and practical mobile applications from the perspective of most practitioners used both for teaching EFL and for independent study have been considered, and a critical review has been done.

An empirical study of the attitude of potential employers and participants in the educational process to mobile devices in professional and educational activities has been carried out; the respondents' perception of mobile applications has been determined. Mobile applications that are most often used have been identified. In addition, the research findings allow concluding that educational process participants support the introduction of m-learning technologies in education. The main obstacles to the implementation of mobile learning are a lower level of acceptance of technology by teachers, relatively low penetration of technology into university education in the developing countries under study, and technical problems. The possibility of introducing MALL into teaching practice has been investigated.

In the course of the study, the problem of the feasibility and necessity of mobile applications in teaching foreign languages has also been identified, and the principles of selecting educational activities based on the use of mobile applications have been developed and substantiated. This research aims to identify several fundamental learning problems and the implementation of MALL technology to overcome them.

The identified educational advantages make it possible to consider mobile learning as one of the critical technologies for teaching EFL in the coming years, in addition to the traditional teaching method. The problems of mobile applications are the lack of user content differentiated by the proficiency levels, the cost of applications, and the 
search for suitable smartphones for effective student learning. Thus, the recommendation from the work findings is that mentioned problems must be overcome to enable more productive use of mobile applications. In this regard, the study of mobile applications suitable for specific aspects of learning a foreign language can be considered a promising research area. MALL technology in teaching foreign languages can act as a basis for finding individual solutions to overcome the found obstacles.

The current study results can pave the way for further comparative research to study the principles, features, and potential of mobile foreign language learning in the UAE and other countries. Further research can also focus on identifying the most popular mobile applications for learning foreign languages in the UAE and other countries, as well as their advantages and disadvantages; analyzing the attitude of the learners to the implementation of mobile applications in professional and educational activities; substantiating the feasibility and necessity of the use of mobile applications in the educational process and in teaching foreign languages.

\section{Acknowledgment}

This paper has been partly supported (for Elena Dolzhich and Svetlana Dmitrichenkova) by the RUDN University Strategic Academic Leadership Program.

\section{$7 \quad$ References}

[1] Biswas, B., Roy, S.K., Roy, F. (2020). Students Perception of Mobile Learning during COVID-19 in Bangladesh: University Student Perspective. Aquademia, 4(2): ep20023. https://doi.org/10.29333/aquademia/8443

[2] Gangaiamaran, R., Pasupathi, M. (2017). Review on use of mobile apps for language learning. International Journal of Applied Engineering Research, 12(21): 11242-11251.

[3] Kuimova, M., Burleigh, D., Uzunboylu, H., Bazhenov, R. (2018). Positive effects of mobile learning on foreign language learning. TEM Journal, 7(4): 837-841.

[4] Godwin-Jones, R. (2017). Smartphones and language learning. Language Learning \& Technology, 21(2): 3-17.

[5] Haerazi, H., Utama, I.M.P., Hidayatullah, H. (2020). Mobile applications to improve English writing skills viewed from critical thinking ability for pre-service teachers. International Journal of Information Management, 14(7): 58-72. https://doi.org/10.3991/ijim. v14i07.11900

[6] Soboleva, E.I., Zamarueva, I.V. (2018). Mobile learning as an effective method of foreign language learning. In Materials of II International scientific and practical conference "Readings of A.I. Bulatov", Conference bulletin, vol.7, Publishing House - South, Krasnodar, March 31, 2018, pp.121-123.

[7] Soboleva, E.I., Kupavskaya, A.A. (2015). Remote education as effective form of independent training. Scientific Works of the Kuban State Technological University, 11: 149-156.

[8] Papadakis, S., Vaiopoulou, J., Kalogiannakis, M., Stamovlasis, D. (2020). Developing and exploring an evaluation tool for educational apps (ETEA) targeting kindergarten children. Sustainability, 12: 4201. https://doi.org/10.3390/su12104201

[9] Papadakis, S. (2020). Tools for evaluating educational apps for young children: a systematic review of the literature. Interactive Technology and Smart Education, in press. https://doi.org/ 10.1108/ITSE-08-2020-0127 
[10] Beloglazov, A.A., Beloglazova, L.B., Beloglazova, I.A., Trubacheev, E.V., Maltsev, O.L., Kletskin, A.A., Pechersky, D.K., Blokhin, M.R. (2018). The use of m-learning technologies in higher education: problems and perspectives. RUDN Journal of Informatization in Education, 15(4): 432-442. https://doi.org/10.22363/2312-8631-2018-15-4-432-442

[11] Kalogiannakis, M., Papadakis, S. (2019). Evaluating pre-service kindergarten teachers' intention to adopt and use tablets into teaching practice for natural sciences. International Journal of Mobile Learning and Organisation, 13(1): 113-127. https://doi.org/10.1504/ IJMLO.2019.096479

[12] Papadakis, S. (2018). Evaluating pre-service teachers' acceptance of mobile devices with regards to their age and gender: a case study in Greece. International Journal of Mobile Learning and Organisation, 12(4): 336-352. https://doi.org/10.1504/IJMLO.2018.10013372

[13] Damyanov, I., Tsankov, N. (2018). Mobile apps in daily learning activities. International Journal of Information Management, 12(6): 133-140. https://doi.org/10.3991/ijim. $\underline{v 12 i 6.9659}$

[14] Lotherington, H. (2018). How mobile are top-rated mobile language learning apps. In Proceedings of 14th International Conference Mobile Learning, 2018, pp.121-128.

[15] Khalitova, L., Gimaletdinova, G. (2016). Mobile technologies in teaching English as a foreign language in higher education: a case study of using mobile application Instagram. In Proceedings of ICERI2016 Conference, Seville, Spain, November 14-16, 2016, pp. 6155-6161. https://doi.org/10.21125/iceri.2016.0395

[16] Al-Kaisi, A.N., Arkhangelskaya, A.L., Rudenko-Morgun, O.I. (2021). The didactic potential of the voice assistant "Alice" for students of a foreign language at a university. Education and Information Technologies, 26(1): 715-732. https://doi.org/10.1007/s10639-020-10277-2

[17] Zabolotskikh, A., Zabolotskikh, A., Dugina, T., Tavberidze, D. (2021). Creating individual learning paths in the Moodle plugin for undergraduate students to study English grammar. Education and Information Technologies, 26(1): 617-637. https://doi.org/10.1007/ s10639-020-10278-1

[18] Udina, N.N. (2018). Using online dictionaries for students' autonomous learning. In Proceedings of 12th International Technology, Education and Development Conference, Valencia, Spain, March 5-7, 2018, pp. 9391-9394. https://doi.org/10.21125/inted.2018.2322

[19] Alvarado, N.C., Coelho, D., Dougherty, E. (2016). Mobile apps for ELLs: Supporting language learning with engaging digital tools. Argentinian Journal of Applied Linguistics, 4(1): 43-58.

[20] Lyovina, G.M. (2016). Intensification of teaching Russian as a foreign language: mobile applications. Russian Language Studies, 4: 42-47.

[21] Odinokaya, M., Lebedev, A. (2016). Analysis of good practices media education by mobile applications. European Research, 23: 1-4. https://doi.org/10.20861/2410-2873-2016-23-005

[22] Wagner, M.-N., Kupriyanova, M., Donskaya, M.V., Ovezova, U. (2016). Perspectives of introduction of the mobile-assisted language learning (Mall) technology. International Journal of Environmental \& Science Education, 11(15): 8562-8571.

[23] Al-Shehri, S. (2014). Mobile learning in the Arab world: Contemporary and future implications. In Interdisciplinary mobile media and communications: Social, political, and economic implications. IGI Global, pp. 48-62. https://doi.org/10.4018/978-1-4666-6166-0. $\underline{\mathrm{ch} 003}$

[24] Al-Hunaiyyan, A., Alhajri, R.A., Al-Sharhan, S. (2018). Perceptions and challenges of mobile learning in Kuwait. Journal of King Saud University-Computer and Information Sciences, 30(2): 279-289. https://doi.org/10.1016/j.jksuci.2016.12.001

[25] Chergui, O., Begdouri, A., Groux-Leclet, D. (2017). A classification of educational mobile use for learners and teachers. International Journal of Information and Education Technology, 7(5): 324-330. https://doi.org/10.18178/ijiet.2017.7.5.889 
[26] Eppard, J., Nasser, O., Reddy, P. (2016). The next generation of technology: mobile apps in the English language classroom. International Journal of Information Management, 11(4): 21-27. https://doi.org/10.3991/ijet.v11i04.5293

[27] Boers, F., Webb, S. (2018). Teaching and learning collocation in adult second and foreign language learning. Language Teaching, 51(1): 77-89. https://doi.org/10.1017/ $\underline{\mathrm{S} 0261444817000301}$

[28] Mospan, N. (2018). Mobile teaching and learning English-A multinational perspective. Teaching English with Technology, 18(3): 105-125.

[29] Sung, C.M., Ahmad, M., Mansor, N.R., Rashid, R.A., Abdullah, N.C. (2020). The effectiveness of mobile application in learning Malay foreign language. Journal of Physics. Conference Series, 1529(2020): 042064. https://doi.org/10.1088/1742-6596/1529/4/042064

[30] Senior, J. (2019). Mobile translation apps and second language teaching: What do student's think. In 2019 International Conference on Digitization (ICD), Sharjah, United Arab Emirates, Nov. 18-19, 2019, pp. 135-141. https://doi.org/10.1109/ICD47981.2019.9105728

[31] Abedalla, R.W. (2015). The use of mobile assisted language learning applications in learning Arabic. Issues in Information Systems, 16(2): 63-73.

[32] Alawani, A.S., Singh, A.D. (2017). A smart mobile learning conceptual framework for professional development of UAE in-service teachers. International Journal of Management and Applied Research, 4(3): 146-165. https://doi.org/10.18646/2056.43.17-012

[33] Al-Emran, M., Elsherif, H.M., Shaalan, K. (2016). Investigating attitudes towards the use of mobile learning in higher education. Computers in Human Behavior, 56: 93-102. https://doi.org/10.1016/j.chb.2015.11.033

[34] Kalogiannakis, M., Papadakis, S. (2017). An evaluation of Greek educational Android apps for preschoolers. In Proceedings of the 12th Conference of the European Science Education Research Association (ESERA), Research, Practice and Collaboration in Science Education, Dublin City University and the University of Limerick, Dublin, Ireland, pp. 21-25.

[35] Papadakis, S., Kalogiannakis, M. (2020). A research synthesis of the real value of self-proclaimed mobile educational applications for young children. In Mobile Learning Applications in Early Childhood Education. PsycINFO, pp. 1-19. https://doi.org/10.4018/ 978-1-7998-1486-3.ch001

[36] Papadakis, S., Kalogiannakis, M., Zaranis, N. (2021). Teaching mathematics with mobile devices and the Realistic Mathematical Education (RME) approach in kindergarten. Advances in Mobile Learning Educational Research, 1(1): 5-18. https://doi. org/10.25082/AMLER.2021.01.002

[37] Oz, H. (2014). Prospective English teachers' ownership and usage of mobile devices as m-learning tools. Procedia - Social and Behavioral Sciences, 141(2014): 1031-1041. https:// doi.org/10.1016/j.sbspro.2014.05.173

[38] Wijaya, I.K., Bakri, R.A., Wutun, A.A. (2019). The effectiveness of mobile learning based android in learning English vocabularies. International Journal of Information Management, 13(12): 226-235. https://doi.org/10.3991/ijim.v13i12.11167

[39] Liu, Q., He, X. (2015). Using mobile apps to facilitate English learning for college students in China. Bachelor's thesis in Informatics. University of Borås. https://doi.org/ 10.1007/978-3-319-27433-1

[40] Arvanitis, P., Krystalli, P., Panagiotidis, P. (2016). Applications for mobile assisted language learning: A current field research. In Proc. of 10th International Technology, Education and Development Conference, Valencia, Spain, March 7-9, 2016, pp. 7645-7651. https://doi. org/10.21125/inted.2016.0803

[41] Kohnke, L. (2020). Exploring learner perception, experience and motivation of using a mobile app in L2 vocabulary acquisition. International Journal of Computer-Assisted Language Learning and Teaching, 10(1): 15-26. https://doi.org/10.4018/IJCALLT.2020010102 
[42] Kacetl, J., Klímová, B. (2019). Use of smartphone applications in English language learningachallenge for foreign language education. Education Sciences, 9: 179. https://doi.org/ 10.3390/educsci9030179

[43] Jamaldeen, F.F., Hewagamage, K.P, Ekanayaka, Y. (2018). Design Guidelines for Creating Mobile Language Learning Applications. International Journal of Information Management, 12(3): 52-74. https://doi.org/10.3991/ijim.v12i3.8153

[44] Klimova, B. (2018). Mobile phones and(or) smartphones and their apps for teaching English as a foreign language. Education and Information Technologies, 23: 1091-1099. https://doi.org/ $10.1007 / \mathrm{s} 10639-017-9655-5$

[45] Kramsch, C. (2014). Teaching foreign languages in an era of globalization. Introduction. The ModernLanguageJournal,98(1):296-311.https://doi.org/10.1111/j.1540-4781.2014.12057.x

[46] Peixoto, B., Pinto, D., Krassmann, A., Melo, M., Cabral, L., Bessa, M. (2019). Using virtual reality tools for teaching foreign languages. In WorldCIST'19, AISC 932, pp. 581-588. https://doi.org/10.1007/978-3-030-16187-3_56

[47] Oyelere, S.S., Suhonen, J., Wajiga, G.M., Sutinen, E. (2018). Design, development, and evaluation of a mobile learning application for computing education. Education and Information Technologies, 23(1): 467-495. https://doi.org/10.1007/s10639-017-9613-2

[48] Valeeva, N.G., Pavlova, E.B., Zakirova, Y.L. (2019).M-learning in Teaching ESP-Case Study of Ecology Students. European Journal of Contemporary Education, 8(4): 920-930.

[49] Kohnke, L., Zhang, R., Zou, D. (2019). Using mobile vocabulary learning apps as aids to knowledge retention: Business vocabulary acquisition. Journal of Asia TEFL, 16(2): 683. https://doi.org/10.18823/asiatefl.2019.16.2.16.683

[50] Xu, Q., Peng, H. (2017). Investigating mobile-assisted oral feedback in teaching Chinese as a second language. Computer Assisted Language Learning, 30(3-4): 173-182. https://doi.org/ $\underline{10.1080 / 09588221.2017 .1297836}$

[51] Papadakis, S. (2020). Apps to promote computational thinking concepts and coding skills in children of preschool and pre-primary school age. In Mobile Learning Applications in Early Childhood Education. IGI Global, pp. 101-121. https://doi.org/10.4018/ 978-1-7998-1486-3.ch006

\section{Authors}

Dolzhich Elena Anatolyevna is a PhD in Philological Sciences, Assistant Professor of the Department of Foreign Languages of Engineering Academy of RUDN University, Peoples' Friendship University of Russia (RUDN University), Moscow, Russian Federation.

Dmitrichenkova Svetlana Vladimirovna is a $\mathrm{PhD}$ in Pedagogical Sciences, Head of Department of Foreign Languages of Engineering Academy of RUDN University, Peoples' Friendship University of Russia (RUDN University), Moscow, Russian Federation.

Kamal Mona Ibrahim is an Assistant Professor, Deputy Dean for International Accreditation, English Language Teacher Education, Al-Ain University, United Arab Emirates, and Helwan University, Egypt.

Article submitted 2021-03-25. Resubmitted 2021-05-13. Final acceptance 2021-05-13. Final version published as submitted by the authors. 